\title{
BALANCING FUNDAMENTAL RIGHTS: UNITED IN DIVERSITY? SOME REFLECTIONS ON THE RECENT CASE LAW OF THE EUROPEAN COURT OF JUSTICE ON DATA PROTECTION
}

\begin{abstract}
Maria Tzanou*
Summary: The article examines the role of the ECJ in the balancing of fundamental rights within the EU legal order. In particular, it reflects on the consequences of the pronouncements of the Court of Justice in the Promusicae and Satamedia cases in the field of data protection. It argues that the 'deferential approach' adopted by the Court might affect the coherence of the internal market and fundamental freedoms. More importantly, it contends that it might also have negative implications for the equivalent protection of fundamental rights within the EU legal order. The article goes on to discuss the role that the Court of Justice, as the constitutional court of the EU, should play when 'tough constitutional questions', such as the balancing of fundamental rights, is at stake.
\end{abstract}

\section{Introduction}

The balancing by the European Court of Justice (ECJ) (now: the Court of Justice of the European Union) of fundamental freedoms, ${ }^{1}$ on the one hand, and fundamental rights ${ }^{2}$ on the other, has for years now been at the heart of academic debate. ${ }^{3}$ Prominent cases such as Schmidberger, ${ }^{4}$

\footnotetext{
Maria Tzanou is a PhD Candidate at the European University Institute (Florence, Italy). She holds an LLM in European Law from the University of Cambridge.

1 The term 'fundamental freedoms' refers to the free movement of goods, services, capital and persons, the pillars for the establishment of the common market. See C Kombos, 'Fundamental Rights and Fundamental Freedoms: A Symbiosis on the Basis of Subsidiarity' (2006) 12 European Public Law 433, 435. For a general overview, see inter alia D Wyatt and A Dashwood, European Union Law ( $5^{\text {th }}$ edn Sweet \& Maxwell, London 2006) 535 subseq; C Barnard, The Substantive Law of the EU - The Four Freedoms (OUP, Oxford 2004).

2 The term 'fundamental rights' refers to the rights and principles enshrined in the EU Charter of Fundamental Rights and the ECHR and which result from the constitutional traditions common to the Member States. See Articles 6 (1) and (3) TEU.

3 See inter alia G de Burca, 'The Language of Rights and European Integration' in J Shaw and G More (eds) New Legal Dynamics of European Integration (Clarendon Press, Oxford 1995) 29; J Weiler and N Lockhart, 'Taking Rights Seriously: The European Court and its Fundamental Rights Jurisprudence' (1995) 32 CMLR 51 and 579; F Jakobs, 'Human Rights in the European Union: The Role of the Court of Justice' (2001) ELRev 331; B de Witte, 'The Past and Future Role of the European Court of Justice in the Protection of Human Rights' in P Alston (ed) The EU and Human Rights (OUP, Oxford 1999) 859.

4 Case C-112/00 Schmidberger v Austria [2003] ECR I-5659.
} 
Omega, ${ }^{5}$ Viking ${ }^{6}$ and Laval have been discussed vigorously in the literature and despite a number of nuances over the years, one can no longer seriously question whether the Court 'is taking rights seriously'.

However, new causes of concern seem to have appeared recently. This time, though, the problem does not arise when fundamental rights meet fundamental freedoms, but rather when the Court is engaged in a balancing exercise between fundamental rights themselves. The right to privacy is the ideal vehicle for exploring this tension between fundamental rights. This is because this right clashes routinely with other rights such as the right to property or the freedom of expression. How has the constitutional Court of the European legal order dealt with such cases of 'tough constitutional questions' when the balancing of fundamental rights is at stake?

When asked to strike a fair balance between fundamental rights in the cases of Promusicae ${ }^{9}$ and Satamedia, ${ }^{10}$ the Court refused to provide a clear answer and returned the issue to the Member States. The present article considers this case law and attempts to draw out the implications for the internal market and for the standards of protection of fundamental rights themselves. While it does not dispute the motives and the good intentions of the ECJ, it nevertheless criticises the Court for failing to properly foresee the consequences of its rulings. It will be argued that by sending matters back to the national courts, the ECJ might in effect have endangered the coherence of the internal market and, what is even worse, undermined the equivalent level of protection of fundamental rights in the enlarged EU.

The analysis will proceed as follows. First, it will start by examining the Data Protection Directive, ${ }^{11}$ which is depicted as a paradigm of successful co-existence between fundamental rights and fundamental freedoms (Part 2). In this area, the ECJ will be praised for interpreting an

\footnotetext{
5 Case C-36/02 Omega Spielhallen- und Automatenaufstellungs-GmbH [2004] ECR I9609.

6 Case C-438/05 International Transport Workers' Federation and Finnish Seamen's Union v Viking Line [2007] ECR I-10779.

7 Case C-341/05 Laval un Partneri Ltd $v$ Svenska Byggnadsarbetareförbundet [2007] ECR I-11767.

8 J Coppel and A O’Neill, 'The European Court of Justice: Taking Rights Seriously?' (1992) 29 CMLR, 669.

9 Case C-275/06 Productores de Música de España (Promusicae) v Telefónica de España SAU, Judgment of 29 January 2008.

10 Case C-73/07 Satakunnan Markkinapörssi and Satamedia, Judgment of 16 December 2008.

11 Directive 95/46/EC of the European Parliament and of the Council of 24 October 1995 on the protection of individuals with regard to the processing of personal data and on the free movement of such data, OJ L281 of 23 November 1995, p 31.
} 
internal market instrument in such a way that fosters the protection of a fundamental right. It will then turn to assess the recent case law of the Court concerning the balancing of fundamental rights in the Promusicae and Satamedia cases (Part 3). After this, it will attempt to explore the challenges posed by this case law to the internal market and fundamental rights (Part 4). Based on this analysis, the last section (Part 5) will argue against a deferential approach when the balancing of fundamental rights is at stake and will try to advance a number of normative arguments concerning the role that a constitutional court, such as the Court of Justice, should play in such cases.

\section{The data protection paradigm or when fundamental rights and fundamental freedoms can live in harmony with each other}

\subsection{The Data Protection Directive: a 'successful marriage' of funda- mental rights and freedoms in the $E U$}

\subsubsection{Background to the adoption of the Data Protection Directive}

Directive 95/46/EC ${ }^{12}$ (the 'Data Protection Directive') constitutes the central legislative measure of the EU data protection regime. It is the first piece of legislation adopted at the EU level concerning the protection of individuals with regard to the processing of personal data, and it is still considered to be the most important data protection initiative within the $\mathrm{EU}^{13}$, and 'the leading force of globalizing data protection'14 in the rest of the world.

The negotiations for the adoption of the Data Protection Directive, which took almost five years to complete, provide a good example of the clash between fundamental rights on the one hand, and fundamental freedoms on the other. This was reflected in the approaches adopted by the three main actors involved in the Community's legislative process: the Commission, the Council and the European Parliament. ${ }^{15}$ In particular, while the European Parliament had adopted as early as the 1970s a clear 'fundamental human rights approach', ${ }^{16}$ the Council and the Commission seemed more concerned with the promotion of a European data

\footnotetext{
12 Directive 95/46/EC (n 11).

13 L Bygrave, 'International Agreements to Protect Personal Data' in JB Rule and G Greenleaf (eds), Global Privacy Protection - The First Generation (Edward Elgar, Cheltenham 2008) 15, 31.

14 M Birnhack, 'The EU Data Protection Directive: An Engine of a Global Regime' (2008) 24 Computer Law \& Security Report, 508, 512.

15 A Newman, discusses the role of data privacy authorities in the adoption of the Directive in 'Building Transnational Civil Liberties: Transgovernmental Entrepreneurs and the European Data Privacy Directive' (2008) 62 International Organization, 103, 119.

16 D Heisenberg, Negotiating Privacy: the European Union, the United States and Personal Data Protection (Lynne Rienner Publishers, London 2005) 53; D Campbell (ed) Data Transmission and Privacy (Kluwer Academic Publishers, Dordrecht 1994) 150.
} 
processing industry ${ }^{117}$ and the facilitation of transborder data flows. The European Parliament had asked the Commission three times (in 1976, 1979 , and 1982) to propose a directive in order to harmonise data protection regulations across the EC. The Commission only provided a first draft of a directive harmonising data protection legislation in 1990. This draft was largely inspired by the German and French data protection laws, and thus had fundamental rights as its central focus. What has been characterised by one author ${ }^{18}$ as 'Germany's disproportionate influence' on this first Commission draft was mainly a consequence of the significant contribution of Hesse's data protection commissioner, Spiros Simitis, who acted as the Chairman of the Commission's drafting group. Simitis, who also held the Chair of the Council of Europe's Data Protection Experts Committee, was keen to emphasise that the fundamental human rights aspect of the Directive could not be traded off against other interests. ${ }^{19}$ It is hardly surprising that this position was not welcomed by certain Member States within the Council, in particular the UK, which did not see any need for the harmonisation of data protection rules at the EC level. Furthermore, the Commission's proposal was severely criticised by trade and industry on the grounds that it was too bureaucratic and gave a clear priority to the protection of personal data at the expense of other objectives such as the need for the commercial exchange of data. ${ }^{20}$

In view of these criticisms, the Commission submitted a second amended draft in October 1992. The tensions within the Council between the different Member States were obvious even after this second proposal. The UK continued to object to a directive that would harmonise data protection laws in Europe to a higher degree than the UK standard. However, in the end it chose to abstain rather than vote against the Di-

\footnotetext{
17 A Nugter, Transborder Flow of Personal Data within the EC (Kluwer Law and Taxation Publishers, Boston 1990) 32.

18 Heisenberg (n 16) 55.

19 'While the traditional four freedoms may still play a crucial role, the Union's explicit commitment to the fundamentals of a democratic society entails the duty to respect the basic rights of its citizens. Indeed, the Member States, rather than simply relying on the decisions of the European Court, stressed the importance of these rights and the necessity of safeguarding them in the Maastricht Treaty.

Against this background, the Commission not only paved the way for a Directive, but also expressly declared its 1990 proposals to be an immediate consequence of the European Community's duty to guarantee the fundamental rights of its citizens.

The Commission's change of position has ... far-reaching consequences ... The Commission ... must give a clear preference to a regulatory scheme that best secures the protection of the individuals concerned. In other words, the commitment to fundamental rights forces the Commission to achieve not merely some level of protection, but protection of "a high degree," which in the Union's language means the maximum possible.' S Simitis, 'From the Market to the Polis: The EU Directive on the Protection of Personal Data', (1995) 80 (3) Iowa Law Review 440, 447-448.

20 The Union of Industrial and Employers' Confederations in Europe (UNICE) stated in March 1991 its objections to the Directive, claiming it would potentially lead to 'a fortress Europe' by cutting off data flow to countries that did not have as strict data protection laws. See Tech Europe, 1 March 1991.
} 
rective. The Directive was finally signed by the Presidents of the Council and the European Parliament on 24 October 1995, giving Member States a period of three years for transposition into domestic law. ${ }^{21}$

\subsubsection{Objectives and legal basis}

The Data Protection Directive aims to harmonise the different national rules on the protection of personal data by simultaneously ensuring the free movement of such data. In this respect, it can be seen on the one hand as a 'negative harmonisation' instrument to the extent that it intends to remove obstacles to the establishment of the internal market by ensuring and facilitating the free trade of data between different Member States. However, on the other hand, it can be considered as a measure of 'positive harmonisation' in that it replaces the divergent data protection regimes across the Community with a harmonised EC regulatory framework which establishes a high level of protection of personal data. To this end, Recital 3 of the Directive states that

... the establishment and functioning of an internal market in which ... the free movement of goods, persons, services and capital is ensured require not only that personal data should be able to flow freely from one Member State to another, but also that the fundamental rights of individuals should be safeguarded.

This linking by the Directive of the two seemingly conflicting principles of free trade and data protection was not immune from criticism both from the point of view of fundamental rights protection and also from the standpoint of business interests. The major concern regarding fundamental rights was whether the protection of the right to privacy and of personal data was in fact totally subordinate to internal market prerogatives. One commentator did not hesitate to characterise the Commission as a 'European Midas' in that everything it touches becomes a market. ${ }^{22}$ On the other hand, concerns about the need to establish a fundamental right to privacy and data protection at the EU level were (and still are) also voiced. ${ }^{23}$ According to one author, the EU data protection regime imposes an onerous set of requirements on all sectors of industry,

\footnotetext{
${ }_{21}$ All Member States have implemented Directive 95/46 in their national legislation. See 'Status of Implementation of Directive 95/46 on the Protection of Individuals with regard to the Processing of Personal Data', available at <http://ec.europa.eu/justice_home/fsj/ privacy/law/implementation_en.htm> accessed 10.05.2010.

22 S Gutwirth, Privacy and the Information Age (Rowman \& Littlefield, Oxford 2002) 91-92. 23 See for instance L Bergkamp, 'EU Data Protection Policy - The Privacy Fallacy: Adverse Effects of Europe's Data Protection Policy in an Information-Driven Economy' (2002) 18 Computer Law \& Security Report 31, 33. Bergkamp notes that 'Data protection as currently conceived by the EU is a fallacy. It is a shotgun remedy against an incompletely conceptualized problem. It is an emotional, rather than rational reaction to feelings of discomfort with expanding data flows. The EU regime is not supported by any empirical data on privacy risks and demand'.
} 
from financial institutions to consumer goods companies, and from list brokers to employers. ${ }^{24}$

The present paper does not intend to dwell further on the analysis of potential tensions between the right to data protection and the fundamental freedoms of the internal market. However, two points should be advanced here. First of all, after more than fifteen years of the Data Protection Directive, where the right to privacy and fundamental freedoms seemed to have co-existed in harmony, the criticisms above appear rather unsubstantiated. Secondly, an important development that took place in EU primary constitutional law, and which has its roots in the Data Protection Directive itself, should not go unnoticed. This regards the enshrining of the right to data protection as an autonomous fundamental right in the EU Charter of Fundamental Rights (EUCFR). ${ }^{25}$ Until recently, the right to personal data protection (or the right to informational selfdetermination') was considered to be an aspect of the right to privacy. ${ }^{26}$ However, the protection of personal data at the EU level is now conceived of as featuring an autonomous fundamental right distinct from the right to respect for private and family life, ${ }^{27}$ since it is specifically enshrined as a fundamental right in Article 8 of the EUCFR. ${ }^{28}$

24 Bergkamp (n 23, 37) also observes that 'EU policy ... is driven by paternalistic motives; individuals need to be protected and be given inalienable but vague fundamental rights, the scope of which government officials define ex post in specific cases'.

${ }_{25}$ The Charter of Fundamental Rights of the European Union proclaimed on 7 December 2000 in Nice (OJ C 364/1).

26 Privacy and data protection are not identical rights. While data protection is generally considered as an aspect of the right to privacy, it is however to be distinguished from it, since it applies to all personal data and is not limited to data related to the private or family life of a person. Data protection is defined in Article 1 of the 1981 Convention for the Protection of Individuals with regard to Automatic Processing of Personal Data (also known as 'Convention 108 ') as the protection of the right to privacy of the individual with regard to automatic processing of personal data relating to him'. In fact, data protection rules are frequently justified and explained as an attempt to counter the perceived threat to informational privacy as a consequence of the increased use of computers and other processing means in the contemporary information society. See Tzanou 'Data Protection in EU Law: An overview of the Legal Instruments' in C Akrivopoulou, and A Psygkas (eds) Personal Data Privacy and Protection in a Surveillance Era: Technologies and Practices (IGI Global, Hershey) forthcoming.

27 N Skandamis, F Sigalas and S Stratakis, 'Rival Freedoms in Terms of Security: The Case of Data Protection and the Criterion of Connexity', Research Paper No 7, December 2007, 5. Available at <http://www.ceps.eu>.

28 Article 8 EUCFR reads as follows:

1. Everyone has the right to the protection of personal data concerning him or her.

2. Such data must be processed fairly for specified purposes and on the basis of the consent of the person concerned or some other legitimate basis laid down by law. Everyone has the right of access to data which has been collected concerning him or her, and the right to have it rectified.

3. Compliance with these rules shall be subject to control by an independent authority'. See also the Commentary of the Charter of Fundamental Rights of the EU, EU Network of Independent Experts on Fundamental Rights, June 2006, available at 
Turning now to the legal basis of the Data Protection Directive, it was adopted under Article 95 of the EC Treaty (now 114 TFEU), which concerns the approximation of legislation relating to the internal market. According to Recital 7 of the Directive:

... the difference in levels of protection of the rights ... to privacy, with regard to the processing of personal data afforded in the different Member States may prevent the transmission of such data from the territory of one Member State to that of another Member State; ... this difference may therefore constitute an obstacle to the pursuit of a number of economic activities at Community level, distort competition and impede authorities in the discharge of their responsibilities under Community law.

It is thus very interesting to note that the Directive was intended as a harmonisation instrument, which by establishing an equivalent level of protection of personal data would allow for their free movement in the internal market. However, it should be mentioned here that the Directive did not intend to establish merely a certain level of equivalent protection of the right to privacy within the Community, but protection of a 'high' degree. ${ }^{29}$

Against this background, this article argues that the right to privacy, in particular data protection, and the fundamental freedoms of the internal market have succeeded in living together harmoniously under the auspices of the Data Protection Directive. However, this would have been impossible without the generous interpretation of this measure by the Court of Justice, which will be analysed in the following section.

\subsection{Interpreting an internal market measure to foster the protecti- on of fundamental rights: The case law of the Court of Justice on data protection}

If we attempt a general comment on the ECJ's reading of the Data Protection Directive, this would be that the Court, in essence, has inter-

\footnotetext{
<http://ec.europa.eu/justice/doc_centre/rights/charter/docs/network_commentary_ final\%20_180706.pdf $>$ accessed 13.11.2010. The enshrining of the right to data protection as a fundamental right within the European legal order is not free from criticism. L Bergkamp (n 24, 31, 33) argues that: 'An unfortunate consequence of including this right among truly fundamental rights, such as the prohibition of torture and slavery and the freedom of expression, is that the notion of fundamental right seriously devaluates, with adverse consequences for the respect for the core human rights'.

29 Recital 10 of the Data Protection Directive states: '... the object of the national laws on the processing of personal data is to protect fundamental rights and freedoms, notably the right to privacy, which is recognised both in Article 8 the ECHR and the general principles of Community law; whereas, for that reason, the approximation of those laws must not result in any lessening of the protection they afford, but must, on the contrary, seek to ensure a high level of protection in the Community'. (emphasis added)
} 
preted an internal market harmonisation instrument (the Directive) in a manner that fosters the protection of a fundamental right within the Community. ${ }^{30}$ In this respect, it has adopted an expansive reading of the protective scope of the Directive which goes beyond the exercise of economic activities, and a restrictive one concerning the exemptions not covered by it.

This flexible interpretation of the Directive is best illustrated in two important cases of the jurisprudence of the Court concerning the scope of application of the Data Protection Directive. Österreichischer Rundfunk ${ }^{31}$ was a preliminary ruling case which concerned the compatibility with Community law of an Austrian provision requiring entities which were subject to control by the Austrian Court of Auditors, the Rechnungshof, to inform the latter of the salaries of their employees when they exceeded a certain level. Subsequently, the Rechnungshof would publish this information in a report which contained the names of the persons and the level of their respective salaries. In this case, the Court was asked to rule whether the Data Protection Directive was applicable at all to this control activity exercised by the Rechnungshof. Unlike Advocate General Tizzano, who pleaded against the applicability of the Directive, the ECJ found that it was applicable. According to the Court, 'since any personal data can move between Member States, Directive 95/46 requires in principle compliance with the rules for protection of such data with respect to any processing of data as defined by Article 3'. ${ }^{32}$ The ECJ rejected the argument that the Data Protection Directive applies only to activities which have a sufficient connection with the exercise of the fundamental freedoms of the common market by holding that recourse to Article 95 EC as a legal basis 'does not presuppose the existence of an actual link with free movement between Member States in every situation referred to by the measure founded on that basis'. ${ }^{33}$ If a contrary interpretation had been adopted, it would have made the limits of the field of application of

\footnotetext{
30 Tzanou (n 26). As the Data Protection Supervisor P Hustinx points out: 'Data protection is more and more considered as a "horizontal" issue of a wider relevance than the well being of the internal market'. See P Hustinx, 'Data Protection in the EU' (2005) P\&1, 62, 64.

31 Joined Cases C-465/00, C-138/01 \& C-139/01, Österreichischer Rundfunk, Judgment of 20 May 2003, Full Court, [2003] ECR I-4989.

32 Österreichischer Rundfunk (n 31) para 40.

33 Österreichischer Rundfunk (n 31) para 41 (emphasis added). Classen (CD Classen, (case note) [2004] 41 CMLR, 1377, 1382) argues that: 'But it is, above all, questionable ... [that the Court] took no account of the limits of the legal basis in the Treaty when dealing with the question how to define the scope of a provision of secondary legislation. Article $95 \mathrm{EC}$ is not a sufficient legal basis for a Directive applying within the whole scope of Community law. The Court of Justice did not even try to find any relation to the internal market beyond the realization of fundamental freedoms ... the present decision is particularly disappointing. Certainly it proves the increasing interest of the ECJ in human rights questions, but this does not exonerate the Court from the obligation to examine the applicability of Community law - a criticism which can be addressed also towards some other recent judgments.'
} 
the Data Protection Directive particularly unsure and uncertain, which would have been contrary to its essential objective, which is the harmonisation of the data protection rules of the Member States in order to eliminate obstacles and ensure the free movement of personal data within the internal market. ${ }^{34}$

The same wide interpretation of the scope of the Data Protection Directive was reiterated in Lindquist. ${ }^{35}$ Before moving to the reasoning of the Court, it is worth taking a closer look at the Opinion of the Advocate General. In particular, Advocate General Tizzano reasoned against the applicability of the Data Protection Directive to the processing of personal data that consisted of setting up an internet page as an ancillary activity to Mrs Lindqvist's voluntary work as a catechist in a parish of the Swedish Protestant Church. To refute the Commission's argument that Mrs Lindqvist's activity fell within the scope of the Directive, as it was not confined to the pursuit of economic objectives but also had objectives connected with social imperatives and the protection of fundamental rights, the Advocate General observed that the need to safeguard the fundamental rights of individuals in order to ensure a high level of protection of these rights "was conceived in the course of and with a view to achieving the main objective of the Directive, namely the free movement of personal data inasmuch as it is held to be "vital to the internal market"'.36 According to the Advocate General, contributing to economic and social progress and safeguarding fundamental rights represent important values and imperatives which the Community legislature took into account in framing the harmonised rules required for the establishment and functioning of the internal market, but they are not independent objectives of the Directive. ${ }^{37}$ In accordance with its legal basis, Directive 95/46 has, in the view of the Advocate General, as its principal objective the guaranteeing of the free movement of data within the internal market. Thus, the harmonisation of national legislation on the protection of personal data is only a means of guaranteeing free movement of personal data. This means that, although it calls upon the Member States to adopt a harmonised system of protection of personal data, the Directive is not a norm for the protection of fundamental rights. To support this analysis, Advocate General Tizzano adopted a strict reading of the principle of 'attributed competences' and recalled that the European Community does not have any general competence to design provisions protecting fundamental rights. On the basis of Article 95 EC, the Community legislature did not

34 Österreichischer Rundfunk (n 31) para 42.

35 Case C-101/01 Bodil Lindquist [2003] ECR I-12971. L Coudray, (case note) [2004] 41 CMLR, 1361.

36 Opinion of Advocate General Tizzano in Case C-101/01 Bodil Lindquist, 19 September 2002, para 40.

37 Opinion of Advocate General Tizzano (n 36) para 41. 
have the competence to design an act guaranteeing, in all cases, the protection of fundamental rights. Thus, far from offering general protection to individuals, the Directive, according to the Advocate General, applies only to activities within the scope of Community law.

The Court of Justice did not adopt this approach. It stressed once more that a distinction should be made between the general objective of an act adopted on the basis of Article $95 \mathrm{EC}$ and the specific situations where this act can be applied, even if these are not directly linked to the internal market. The ECJ clarified that the exception of Article $3(2)^{38}$ applies only to the activities which are expressly listed therein or which can be classified in the same category. As a result, the Directive applies to all other activities regardless of their connection with the internal market. Thus, it applied to the charitable and religious activities carried out by Mrs Lindqvist.

Finally, the ECJ was asked to pronounce on the question of whether it is permissible for the Member States to provide for greater protection for personal data or a wider scope than is required under Directive 95/46'. On this issue, the Court stressed that the Data Protection Directive envisages complete harmonisation. Nevertheless, Member States enjoy a margin for manoeuvre in certain areas and they are authorised to maintain or introduce particular rules for specific situations. In any case, they remain free to regulate the areas excluded from the scope of application of the Directive, provided that no other provision of Community law precludes it.

The two cases cited above illustrate two very important points concerning the jurisprudence of the Court on the Data Protection Directive. First, the ECJ refused to follow the Advocate General's line of reasoning and consider fundamental rights (in this case, privacy) as a secondary purpose or means for the achievement of the internal market objectives of the Directive. Secondly, it also refused to develop a test to establish an 'actual' or 'sufficient' link of certain activities to the internal market in order for them to fall within the scope of application of the Data Protection Directive. By doing so, it managed to ensure legal certainty and thus safeguard and promote the coherence of the internal market itself by ruling out any possibilities of uncertainty as to the particular circumstances of application of the Directive. ${ }^{39}$ Hence, despite the criticisms it received

\footnotetext{
38 Article 3 (2) lays down the cases that fall outside the scope of application of the Directive.

39 Bignami (F Bignami, 'The Case for Tolerant Constitutional Patriotism: The Right to Privacy Before the European Courts' (2008) 41 Cornell International Law Journal, 211, 232) rightly notes that: 'It was clear that the Court's interpretation was driven not so much by the text as by the specter of future litigation. If the Court were to hold otherwise and find that the Directive applied to only market-related activities, how would future courts distinguish between market-related and other activities?'
} 
for this generous interpretation of the Directive, it is to be commended for succeeding in making the 'successful marriage' between fundamental rights and fundamental freedoms, as established by the Community legislator in the Data Protection Directive, even more solid and stronger.

\section{A difficult task: balancing between fundamental rights}

\subsection{Privacy versus property: the Promusicae case $e^{40}$}

While the Court is to be congratulated on its clear pronouncements with regard to the Data Protection Directive concerning the relationship between fundamental rights and fundamental freedoms, its recent judgments in Promusicae and Satamedia reveal that it has found it harder to deal with cases that concern the relationship between fundamental rights themselves.

Let us begin by taking a closer look at the Promusicae ruling, which involved the strained relationship between, on the one hand, the right to privacy, and on the other, the right to property in the information society. The case concerned the refusal of a commercial company which provided internet access services, Telefónica, to disclose to Promusicae, a nonprofit-making organisation of producers and publishers of musical and audiovisual recordings, acting on behalf of its members who were holders of intellectual property rights, personal data of certain persons whom it provided with internet access services. Promusicae sought the disclosure of the above information before the Commercial Court of Madrid in order to be able to bring civil proceedings against those persons who, it alleged, used the KaZaA file exchange program (peer-to-peer) and provided access to shared personal computer files with music which the members of Promusicae held the rights to. The Spanish Court referred the issue to the Court of Justice by asking it essentially whether Community law, in particular Directives 2000/31, ${ }^{41} 2001 / 29^{42}$ and 2004/48, ${ }^{43} \mathrm{read}$ in the light of Articles 17 and 47 of the EUCFR, requires Member States to lay down, in order to ensure effective protection of copyright, an obligation to communicate personal data in the context of civil proceedings.

\footnotetext{
40 On the same question, see also the Case C-557/07 LSG-Gesellschaft zur Wahrnehmung von Leistungsschutzrechten GmbH $v$ Tele2 Telecommunication GmbH judgment of 19 February 2009.

41 Directive 2000/31/EC of the European Parliament and of the Council of 8 June 2000 on certain legal aspects of information society services, in particular electronic commerce, in the Internal Market (Directive on electronic commerce), OJ L 178/1.

42 Directive 2001/29 of the European Parliament and of the Council of 22 May 2001 on the harmonisation of certain aspects of copyright and related rights in the information society, OJ L $167 / 10$.

43 Directive 2004/48 of the European Parliament and of the Council of 29 April 2004 on the enforcement of intellectual property rights, OJ L 157/32.
} 
The Court commenced its analysis by examining secondary Community legislation. It started by taking a look at the provisions of the e-Privacy Directive ${ }^{44}$ and found that this does not preclude the possibility of Member States laying down an obligation to disclose personal data in the context of civil proceedings. ${ }^{45}$ It then turned to consider the three Directives mentioned by the national court, the purpose of which is to ensure an effective protection of industrial property, in particular copyright in the context of the information society. It concluded that these Directives did not contain any provisions that would compel Member States to lay down an obligation to communicate personal data in the context of civil proceedings. ${ }^{46}$ Since the secondary legislation did not provide any clear answer on the issue at stake, the Court turned its attention to primary EU constitutional law, namely fundamental rights.

In this part of its analysis, it noted from the outset that while the fundamental right to property, which includes intellectual property rights such as copyright, and the fundamental right to effective judicial protection constitute general principles of Community law, ${ }^{47}$ the situation in respect of which the national court put the question at issue involved, in addition to these two rights, a further fundamental right, namely the right that guarantees the protection of personal data and hence of private life. ${ }^{48}$ This is a rather remarkable pronouncement because it was the first time that the Court expressly recognised that the right to data protection enjoys the status of a fundamental right within the Community legal order. It did so by looking at Article 8 of the EUCFR, which as seen above, expressly proclaims the right to data protection. It seems, though, that the ECJ in this case went one step further than its existing case law concerning the Charter. Until Promusicae, if a right was contained in the Charter, this created a presumption that it was protected under the general principles of Community law. ${ }^{49}$ In Promusicae, however, the fact that the protection of personal data was enshrined in the Charter was enough for the Court of Justice to identify it as an autonomous fundamental right. ${ }^{50}$

Notwithstanding this significant development, the Court seemed to have a hard time when faced with the challenge of the reconciliation of

\footnotetext{
44 Directive 2002/58/EC of the European Parliament and of the Council of 12 July 2002 concerning the processing of personal data and the protection of privacy in the electronic communications sector, OJ L 201/37.

45 Promusicae (n 9) para 58.

46 Promusicae (n 9) para 60.

47 Promusicae (n 9) para 62.

48 Promusicae (n 9) para 63 (emphasis added).

49 See M Dougan, 'The Treaty of Lisbon 2007: Winning Minds, not Hearts', 45 CMLR (2008) 617,662 .

50 Tzanou (n 26).
} 
the two fundamental rights, namely the right to respect for private life on the one hand and the rights to protection of property and to an effective remedy on the other. Its pronouncement on the issue and its answer to the national court is contained in a puzzling statement which reads as follows:

Directives 2000/31, 2001/29, 2004/48 and 2002/58 do not require the Member States to lay down, in a situation such as that in the main proceedings, an obligation to communicate personal data in order to ensure effective protection of copyright in the context of civil proceedings. However, Community law requires that, when transposing those directives, the Member States take care to rely on an interpretation of them which allows a fair balance to be struck between the various fundamental rights protected by the Community legal order. Further, when implementing the measures transposing those directives, the authorities and courts of the Member States must not only interpret their national law in a manner consistent with those directives but also make sure that they do not rely on an interpretation of them which would be in conflict with those fundamental rights or with the other general principles of Community law, such as the principle of proportionality. ${ }^{51}$

What is to be made of this enigmatic pronouncement of the Court? Balancing the right to data protection against the right to intellectual property is a daunting task and the practical consequences of passing the issue back to the national court without providing clear guidelines on how a fair balance is to be struck, could prove to be more serious than originally envisaged by the ECJ. The Promusicae case leaves a number of questions unanswered concerning the obligations of Internet Service Providers (ISPs) when violations of copyright by their customers using peerto-peer technologies are at stake. If every Member State is free to settle them independently, then the functioning of the common market is liable to be seriously affected by the differences in the national rules applicable to such processing of personal data. ${ }^{52}$ This is in fact ironic given that all of the secondary legislation in this field to date has been adopted on the premise of promoting further approximation of the internal market. Perhaps what is most significant, however, is the lack of a detailed consideration by the ECJ of the practical consequences of its judgment on the fundamental rights themselves. Given the Court's enhanced commitment

51 Promusicae (n 9) para 70.

52 As Groussot (X Groussot, 'Music Production in Spain (Promusicae) v Telefónica de España SAU - Rock the KaZaA: Another Clash of Fundamental Rights' (2008) 45 CMLR 1745, 1763) has eloquently stressed: 'The disparities between the legislation of the Member States as to liability in civil proceedings endanger the coherence of the internal market. It appears clear that the Community legislature and the Court of Justice in Promusicae have not provided a magic solution for filling those gaps'. 
to fundamental rights in recent years, it is difficult to understand why the ECJ failed to foresee the fact that divergent regulations concerning intellectual property rights in the internal market might also affect the equivalent protection of personal data and of the right to privacy as established by the Data Protection Directive.

\subsection{Privacy versus freedom of expression: the case of Satamedia}

The Court was also called upon to engage in a balancing of fundamental rights in Satakunnan Markkinapörssi and Satamedia. Essentially, it was asked to interpret Article 9 of the Data Protection Directive, which allows Member States to provide for exemptions and derogations regarding the processing of personal data 'carried out solely for journalistic purposes or the purpose of artistic or literary expression only if they are necessary to reconcile the right to privacy with the rules governing freedom of expression'. The case was a preliminary reference made in proceedings between the Finnish Data Protection Ombudsman, the Tietosuojavaltuutettu, and the Finnish Data Protection Board, the Tietosuojalautakunta, relating to activities involving the processing of personal data undertaken by Markkinapörssi and Satamedia. Markkinapörssi had collected public data from the Finnish tax authorities ${ }^{53}$ for the purpose of publishing extracts from them in the regional editions of the Veropörssi newspaper, and transferred the same data to Satamedia with a view to them being disseminated by a text-messaging system.

The Court, in essence, this time had to reconcile the fundamental right to privacy with the fundamental right to freedom of expression. It commenced its analysis by noting the importance of the right to freedom of expression in a democratic society, and held that notions relating to that freedom, such as journalism, should be interpreted broadly. It observed that in order to achieve a balance between privacy and freedom of expression, the derogations and limitations of the right to data protection must apply only in so far as is strictly necessary. ${ }^{54}$ It then clarified that activities, such as those of Satakunnan and Satamedia, which involve the processing of data from documents which are in the public domain under national legislation, may be classified as 'journalistic activities' if their object is 'the disclosure to the public of information, opinions or ideas, irrespective of the medium which is used to transmit them'. ${ }^{55}$ Furthermore, the Court ruled that these activities are not limited to me-

\footnotetext{
53 The information contained in these publications comprised the surname and given name of approximately 1.2 million natural persons whose income exceeds certain thresholds as well as the amount, to the nearest EUR 100, of their earned and unearned income and details relating to wealth tax levied on them.

54 Satamedia (n 10) para 56.

55 Satamedia (n 10) para 61.
} 
dia undertakings but cover every person engaged in journalism, and may be undertaken for profit-making purposes. However, the Court left it to the national court to determine whether this was the case in the main proceedings.

The Court of Justice's unduly broad definition of journalism in this case, which, according to one author 'is tantamount to declaring that all expression must be classified as such', ${ }^{56}$ is very problematic. As Oliver has eloquently put it, 'the Court's open-ended ruling appears to allow national courts virtually unfettered discretion in defining the concept of journalism'. ${ }^{57}$ The consequences of such a laissez-faire approach should not be underestimated; not only may it hinder the free movement of personal data within the European Union, it could also potentially result in creating differing standards of protection of the right to privacy throughout the Union, especially because the Court again failed to give national courts sufficient guidelines to determine how the balance should be struck to sufficiently guarantee the right to privacy. Once again, one might logically wonder why the Court, which over all these years has placed considerable emphasis on the goal of safeguarding the coherence of the internal market by guaranteeing equivalent protection for personal data across Europe, seems to be endangering the achievement of this very goal through its own jurisprudence.

\subsection{Tolerating national constitutional diversity: the merits of the deferential approach}

It would be wrong to assess the Court's case law concerning fundamental rights by ignoring the fact that the EU itself presents a complex constitutional landscape within which the Union struggles to construct and maintain its own culture and identity while respecting that of its Member States. ${ }^{58}$ Fundamental rights and their balancing are at the heart of this constitutional process. One might thus wonder where the Promusicae and Satamedia cases are to be placed in this constitutional landscape? In other words, how should the constitutional court of the European legal order deal with cases that raise 'tough constitutional questions', such as the balancing between fundamental rights, in order to safeguard its own constitutional identity while at the same time respect that of Member States? Is a deferential approach that refers the matter back to the national court the best solution in such cases? Does such an approach lead to a European culture that is tolerating national consti-

\footnotetext{
56 P Oliver, 'The Protection of Privacy in the Economic Sphere before the European Court of Justice' (2009) 46 CMLR 1443, 1461.

57 Oliver (n 56) 1463

58 JA Sweeney, "A "Margin of Appreciation" in the Internal Market: Lessons from the European Court of Human Rights' (2007) 34 (1) Legal Issues of Economic Integration 27.
} 
tutional diversity? Or does it end up creating more confusion for national judges and legislators? What are the implications of the adoption of a 'margin of appreciation doctrine' in areas heavily regulated by Union law?

One should contemplate these questions in order to understand better the ECJ's deferential approach in Promusicae and Satamedia. The merits of a 'judicial subsidiarity"59 or a 'margin of appreciation doctrine' - in the words of the European Convention of Human Rights - have been emphasised by a number of authors. Starting from the premise that the European constitutional order is 'intrinsically pluralist', ${ }^{60}$ they argue that any effort to impose a hegemonic belief system in the interest of constitutional patriotism would be 'antithetical' to the very character of Europe. ${ }^{61}$ Thus, in order to preserve constitutional tolerance, it is imperative, according to this theory, that the courts and other law-making institutions permit 'legitimate disagreement over the content of that identity'. ${ }^{62}$

Reading the ECJ's judgments in Promusicae and Satamedia against this background, we can see the merits of the deferential approach. By sending the question of the balancing of fundamental rights back to the national courts, the Court of Justice avoided having to pronounce authoritatively on a difficult constitutional issue and hence allowed for considerable national discretion. As pointed out by one author, the fundamental rights balance between privacy and other rights is "by no means a precise science 63 and by holding the national courts responsible for the balancing, the Court acknowledges that the outcome will differ according to each national constitutional culture. In other words, as members of the European constitutional order, the relevant national courts are required to consider both privacy and the other fundamental right at stake, but 'the accommodation' of these two fundamental values is to be distinctive to each constitutional order. ${ }^{64}$ According to this view, it is up to the Court of Justice at some time in the future to give a European answer to the privacy-other fundamental rights conundrum. However, for the time being, the national judge is better placed to resolve such thorny issues following his/her national constitutional tradition. ${ }^{65}$

This deferential approach, albeit with dubious results, is also not unknown in cases where the Court has had to decide on public policy exceptions to market freedoms. The 'Sunday-trading' cases should be

\footnotetext{
59 Kombos (n 1) 435.

60 Bignami (n 39) 217.

61 Bignami (n 39) 218.

62 Bignami (n 39) 218.

63 Bignami (n 39) 218.

64 Bignami (n 39) 218.

65 Bignami (n 39) 218.
} 
recalled here. In a series of cases starting in the mid-1980s, the Court of Justice was called upon by British courts to decide whether local rules prohibiting commerce on Sundays were compatible with the duty to allow for the free movement of goods under the EC Treaty. ${ }^{66}$ In what has been characterised as one of its 'most opaque' judgments, ${ }^{67}$ the ECJ found that such rules could, in principle, be covered by Article 28 of the EC Treaty (now 34 TFEU), because they were liable to reduce trade in goods among Member States. However, they also 'reflect certain political and economic choices in so far as their purpose is to ensure that working and non-working hours are so arranged as to accord with national or regional socio-cultural characteristics'. ${ }^{68}$ The Court left it to the national courts to determine whether the restrictive effects of the Sunday trading ban exceeded the 'intrinsic effects' of the Article 28 EC trade rules. ${ }^{69}$ The case is cited as a positive demonstration of the ECJ's tolerance for national constitutional diversity. ${ }^{70}$ Nevertheless, the practical consequences of the ruling reveal the inadequacy of the Court's analysis. National courts reached conflicting conclusions, ${ }^{71}$ and the matter was referred by the House of Lords back to the ECJ, which finally declared that Article 28 did not apply to legislation prohibiting retailers from opening their shops on Sunday, ${ }^{72}$ because the restrictive effects on trade were not excessive in terms of the social aim pursued by the legislation. ${ }^{73}$

\section{Passing the issue to the Member States: why the Court's deferen- tial approach is problematic}

\subsection{Undermining the 'coherence' of the internal market?}

Despite the merits of the deferential approach, it can be argued that by sending the issue to the national courts, the Court of Justice has overlooked the possible risk of undermining the coherence of the internal market. To better demonstrate this point, we will take a closer look at

\footnotetext{
66 The matter was first referred in Torfaen. See Case C-145/88 Torfaen Borough Council $v$ $B \& Q$ PLC [1989] ECR 3851.

67 Barnard (n 1) 132.

68 Torfaen (n 66) para 13.

69 Torfaen (n 66) para 15.

70 Bignami (n 39) 237 notes that these cases demonstrate that on tough constitutional questions, like the balance between privacy and expression or between human dignity and market rights, the Court of Justice gives precedence to national constitutionalism'.

71 Compare Northcote $J$ in B\&Q $v$ Shrewsbury and Atcham BC [1990] 3 CMLR 535 and Hoffman J in Stoke-on-Trent City Council v B\&Q [1990] 3 CMLR 31 with Allen J in Wellingborough BC $v$ Payless [1990] 1 CMLR 773 and Mustill $\mathrm{J}$ in Smiths-do-it-all v Peterborough $B C$ [1990] 2 CMLR 577.

${ }^{72}$ Case C-169/91 Stoke-on-Trent \& Norwich City Council v B\&Q PLC [1992] ECR I-6635, para 44.

73 Stoke-on-Trent \& Norwich City Council (n 72) para 16.
} 
the situation created in the Member States regarding copyright infringements using peer-to-peer technologies in the aftermath of the Promusicae ruling.

The Court's enigmatic judgment has allowed national legislators to display a significant degree of creativity. ${ }^{74}$ Admittedly, the national solutions are certainly innovative. Nevertheless, such creativity necessarily results in divergent solutions in the different Member States and might have negative implications for fundamental freedoms and the coherence of the internal market.

Most of the time, national legislatures have opted for a bolstering of the role of ISPs in copyright infringement cases. ${ }^{75} \mathrm{~A}$ range of proposals that adopt varying roles for ISP holders has therefore been tabled. Thus, at the one end, we have the so-called ISP 'warning system' solution, which is the one essentially set out in the UK's Digital Economy Bill. ${ }^{76}$ According to this, ISPs notify their subscribers if copyright owners have reported infringement activity linked to their IP address. The ISPs keep track of the number of reports concerning each subscriber and compile an anonymous list of some or all of those who are reported. A court order is then sought by the IPR holders to obtain the personal details of those concerned so that the IPR holders can initiate proceedings against them. ${ }^{77}$ The Bill also introduces the possibility for courts to require ISPs to block access to specified online locations with a substantial proportion of content that infringes copyright. In Spain, a new bill that is likely to be adopted before July 2010 foresees the creation of a new commission that could order the blocking of online services or the withdrawal of infringing content from websites. A court order would, however, be needed if fundamental rights could be threatened. At the other end, we have the notorious, in terms of fundamental rights, French 'three strikes' law. According

\footnotetext{
${ }^{74}$ Kuner (C Kuner, 'Data Protection and Rights Protection on the Internet: the Promusicae Judgment of the European Court of Justice' (2008) 30 (5) European Intellectual Property Review 199) argues that: 'By clarifying that Member States may allow the disclosure of personal data in civil cases, the Court's ruling allows the development of innovative mechanisms that respect data protection rights, while providing for effective enforcement of property rights' (emphasis added).

75 This point is emphasised by Coudert and Werkers. See F Coudert and E Werkers, 'In the Aftermath of the Promusicae Case: How to Strike the Balance?' (2010) 18 (1) International Journal of Law and Information Technology 50.

76 Currently at the Committee stage in the House of Lords. See <http://www.publications. parliament.uk/pa/ld200910/ldbills/001/2010001.pdf> accessed 10.5.2010.

77 Lynskey (Lynskey, 'The Implications of Copyright Infringement on the Right to Data Protection in European Union Law in the Context of Peer-to-peer Technology', Nottingham Conference Proceedings, March 2010) argues that: 'this solution has the advantage that it does not lead to the disclosure of the personal data of the alleged infringers (at least not without the safeguard of a court order) yet there is a chance that the infringement will cease as a result of the communication sent by the ISP. The problem is however that it is not guaranteed that the infringement will cease as a result of the ISP's reminder'.
} 
to this legislation, the internet connection of the user would eventually be cut off once intellectual property rights had allegedly been infringed on three occasions. The law proposed that ISPs would have to inform a regulatory body (HADOPI) upon the 'third strike' and that this regulatory body would then remove the alleged infringer's connection. This proposal (commonly known as 'Hadopi') was rejected by the National Assembly despite strong government support. It was then accepted by the National Assembly on its second reading and also by the Senate, and therefore passed into law. ${ }^{78}$ Other possible solutions to the riddle of balancing data protection and intellectual property that provide for the liability of those who distribute a product have been suggested in the relevant literature.

It is outside the purposes of this article to go through every national proposal concerning infringement of copyright on the internet after the Promusicae case. Suffice it to say that these different national rules arising from the Court's deferential approach in Promusicae might distort the competition between different ISPs within the EU, and might raise obstacles in the exercise of their fundamental freedoms. The same concerns also apply with regard to the recipients of Internet services, ie the customers.

A similar situation might arise from the Satamedia judgment, given the uncertainty it has created regarding the scope of Article 9 of the Data Protection Directive and the permissible exceptions and limitations to the data protection provisions for journalistic purposes. If this scope is to be interpreted differently by national courts according to their constitutional traditions, then there is a risk that the exceptions and derogations from the Data Protection Directive concerning 'journalistic purposes' would not apply in a similar manner throughout the Union, thus undermining the very purpose of the Directive, which is the harmonisation of data protection rules in order to remove obstacles to trade. But even if one accepts that this will not be the case, the mere confusion caused for national judges by the Court's judgment brings to mind the tragicomic situation created in the 'Sunday-trading' cases.

\subsection{Undermining fundamental rights themselves?}

It should be emphasised here that the purpose of the present analysis is not to paint a gloomy picture concerning the eventual impact of the Court's judgments in Promusicae and Satamedia on fundamental freedoms. In the end, it might (hopefully) be the case that these criticisms

78 LOI $\mathrm{n}^{\circ}$ 2009-669 du 12 juin 2009 favorisant la diffusion et la protection de la création sur internet. See <http://legifrance. gouv.fr/affichTexte.do;jsessionid=3669EOFCB4 D87ED37C2C3517BF5B6BB5.tpdjo11v_1?cidTexte=LEGITEXT000020736830\&dateTex te $=20100202>$ accessed 10.5.2010. 
are not sufficiently justified in so far as the divergent laws and national courts' decisions produce no more than negligible effects on the coherence of the internal market. The main purpose is rather to demonstrate the implications of these judgments for the fundamental rights themselves. These have arisen precisely because the Court chose for its own reasons ${ }^{79}$ not to provide a centralised, authoritative decision on the issue of balancing. Unfortunately, here the picture will have to be gloomy.

Let us start by taking a look at the implications for the right to privacy, and fundamental rights in general, of the national laws adopted in the aftermath of the Promusicae case concerning copyright protection on the internet. The example of the draconian, in terms of its consequences, Hadopi Law lies at the very centre of this gloomy human rights picture. The Hadopi Law does not only raise serious concerns regarding the right to privacy. In fact, when the law was challenged before the Conseil Consitutionnel, the Court did not hesitate to stress the importance of freedom of expression for participation in democratic life, which also includes the freedom to access communications services online as a result of the development of the internet. The Court held therefore that the power provided by the law to sanction individuals by restraining or preventing their access to the internet as subscribers was incompatible with this right. According to the Conseil Consitutionnel, this power to sanction could only be exercised by the judiciary. The Court also held that by obliging the internet subscriber to prove that an alleged copyright infringement had been committed by a third party, the presumption of innocence set out in Article 9 of the Declaration was also violated. As a result of these breaches, the Constitutional Court struck down the provisions in the Hadopi Law concerned with the imposition of sanctions.

It is also beyond doubt that the Hadopi Law's compatibility with the right to privacy and the personal data protection of individuals is disputable, since the Law essentially introduces a generalised control over electronic communications. Similar concerns also apply to the UK's Digital Economy Bill, which provides for the possibility of ISPs to take measures to limit the internet access of certain subscribers who are allegedly repeat infringers by capping their bandwidth or shaping it in such a way that the subscriber would no longer be able to file-share, or even by temporarily suspending their broadband connection. It should be recalled that Advocate General Kokott noted in Promusicae that it may be doubted whether the storage of traffic data of all users without any concrete suspicions - laying in a stock, as it were - is compatible with

\footnotetext{
79 Above, we read the Court's deferential approach as a demonstration of its commitment to national constitutional diversity. Oliver (n 61, 1483) attributes it to the Court's 'eagerness to avoid being subsequently wrong-footed by the ECtHR'.
} 
fundamental rights'. ${ }^{80}$ The Article 29 Working Party has also voiced its opposition to such a storage obligation, stating that 'ISPs can[not] ... be obliged, except in specific cases where there is an injunction of enforcement authorities, to provide for a general "a priori" storage of all traffic data related to copyright'. In Promusicae, it seems that the Court of Justice side-stepped these considerations by finding that Member States may provide for exemptions to the confidentiality obligation imposed on ISPs by the $e$-Privacy Directive when it is necessary for the protection of the rights and freedoms of others. However, it is arguable whether legislation such as the Hadopi Law (and the Digital Economy Bill) passes the test of proportionality as elaborated by the European Court of Human Rights in its Article 8 ECHR case law. ${ }^{81}$

Satamedia is a more recent case and its practical consequences for fundamental rights are not entirely visible yet. Leaving aside the fact that Finland might be responsible for the incorrect implementation of the Data Protection Directive as regards Article 9, in so far as Finnish law in general excludes the processing of personal data for purposes of journalism or artistic or literary expression in almost every case and not only when it is necessary as stipulated by the Directive, 82 the fact that the Court gives such leeway to Member States in the interpretation of exceptions to data protection for journalism might prove problematic. One cannot deny of course that the ECJ's judgment is quite understandable, at least if we take into account that it followed the same path in the earlier Lindquist case, where it also had to weight the right to privacy against freedom of expression in the context of the conduct of religious activities. The fact that in this case the Court sent the issue back to the national court to decide was welcomed by certain commentators.83 However, the results of Satamedia concerning the right to privacy (or fundamental rights in general) still remain to be seen in practice.

\section{Conclusions: The ECJ as a new Pythia. How to interpret its 'oracles' in favour of the internal market and fundamental rights?}

The present article has examined the consequences for both fundamental freedoms and fundamental rights of the ECJ's judgments in the Promusicae and Satamedia cases. It should be noted that a separate

\footnotetext{
80 Opinion of Advocate General Kokott in Promusicae, 18 July 2007, para 82.

81 See, for instance, the Leander $v$ Sweden judgment of 26 March 1987, Series A no 116, p 22, para 48

82 W Hins, Case C-73/07 Satakunnan Markkinapörssi and Satamedia, Judgment of 16 December 2008, not yet reported (2010) 47 CMLR, 215, 232.

83 Bignami (n 39, 244) notes that: 'The Lindquist judgment both affirmed a European commitment to privacy and free expression and made room for diverse moral orderings of public life at the national level'.
} 
assessment of the implications of these cases for the internal market on the one hand, and fundamental rights on the other is somewhat artificial given that both these purposes are inextricably intertwined and in any case put on an equal footing in the Data Protection Directive, which does not prioritise either of these objectives over the other. However, this approach has been advanced for the sake of the clarity of the analysis.

This close relationship between fundamental rights and fundamental freedoms in the Directive reveals that by not providing a clear answer to the balancing of fundamental rights in Promusicae and Satamedia, the Court might have endangered both. In this respect, it has been demonstrated that different national rules might have implications not only for the coherence of the internal market, but also the equivalent level of protection of fundamental rights in the enlarged EU.

Does this mean that the Court should have settled once and for all the issue of the balancing of fundamental rights? Had it opted for this solution, it would still have been severely criticised, this time most probably by national constitutional courts that are keen to safeguard their constitutional identity. The present paper regrets, however, the fact that the constitutional court of the EU legal order failed to provide clearer guidelines to the national courts. The rationale of the Data Protection Directive, adopted on the basis of Article $95 \mathrm{EC}$, is to serve the establishment of the internal market by ensuring a high level of harmonised protection of a fundamental right. If this project meets with practical difficulties, it is the role of the Court of Justice, as the constitutional Court of the EU legal order to put 'more effort into it', ${ }^{84}$ instead of leaning backwards and passing the 'hot potato' to the Member States.

Stressing the importance of the principle of proportionality is not a panacea, especially when tough constitutional questions are at stake. In the two cases discussed here, one can notice the resemblance of the Court's pronouncements to the oracles of Pythia in ancient Greece. Pythia was the priestess at the Temple of Apollo at Delphi, who sat on her tripod seat and delivered enigmatic, equivocal prophesies that could be interpreted in many different ways. It seems that the ECJ in Promusicae and Satamedia has also left a number of serious issues unanswered for national courts and legislators.

84 Hins (n 82) 231. 